Exercices Exercices de rhétorique

de rhétorique $14 \mid 2020$

La polémique chez les Pères de l'Église

\title{
Lettre 50
}

Traduction par Pierre Descotes

\section{Augustin}

\section{(2) OpenEdition}

\section{Journals}

Electronic version

URL: http://journals.openedition.org/rhetorique/989

DOI: $10.4000 /$ rhetorique.989

ISSN: 2270-6909

\section{Publisher}

UGA Éditions/Université Grenoble Alpes

\section{Printed version}

ISBN: 978-2-37747-186-7

\section{Electronic reference}

Augustin, «Lettre 50 », Exercices de rhétorique [Online], 14 | 2020, Online since 04 March 2020, connection on 12 September 2020. URL : http://journals.openedition.org/rhetorique/989 ; DOI : https://doi.org/10.4000/rhetorique.989

This text was automatically generated on 12 September 2020

\section{(c) (i) () (2)}

Les contenus de la revue Exercices de rhétorique sont mis à disposition selon les termes de la Licence Creative Commons Attribution - Pas d'Utilisation Commerciale - Partage dans les Mêmes Conditions 4.0 International. 


\title{
Lettre 50
}

\author{
Traduction par Pierre Descotes
}

\section{Augustin}

En 399 à Sufétana, des païens réagirent avec une extrême violence à la destruction, par les chrétiens, d'une statue d'Hercule. Soixante chrétiens furent massacrés à cette occasion. L'évêque d'Hippone leur écrivit une brève lettre mordante, qui constitue un cas exceptionnel dans sa correspondance : l'expression d'une colère froide, au service de laquelle Augustin met toutes les ressources de son art oratoire. L'évêque d'Hippone utilise ici une des armes de la polémique : l'ironie.

\section{Augustin évêque, aux chefs, aux responsables et aux anciens de la colonie de Sufétana / Ductoribus ac principibus vel senioribus coloniae Sufetanae, Augustinus episcopus ${ }^{1}$}

1 Le bruit retentissant du crime qu'a commis votre sauvagerie, et sa cruauté inattendue, font trembler la terre et ébranlent le ciel : on peut sur vos places et dans vos temples voir briller le sang et entendre les échos du massacre. Dans votre ville les lois romaines ont été enterrées, la terreur qu'inspirent de droits jugements, foulée aux pieds. Nul respect, nulle crainte des empereurs, assurément. Dans votre ville a coulé le sang innocent de soixante de nos frères, et c'est celui qui en a tué le plus qui s'est trouvé couvert de louanges et a obtenu la première place dans votre sénat. Eh bien, venons-en au sujet principal! Si vous prétendez que cet Hercule était à vous, soit, nous vous le rendrons : nous avons les métaux, les pierres ne manquent pas, on trouve toutes les sortes de marbre, une foule d'artisans se presse. D'ailleurs, votre dieu, on s'empresse pour le sculpter, le polir, l'orner. Nous y ajoutons encore une touche de peinture pour lui faire le teint rouge, et donner de l'éclat à vos vœux solennels! Car si vous prétendez 
que cet Hercule est à vous, nous nous cotisons pour acheter à votre sculpteur un dieu, et vous l'offrir. Mais alors rendez-nous les âmes que votre main criminelle a arrachées, et tout comme nous vous restituons votre Hercule, rendez-nous les âmes d'hommes si justes!

Immanitatis uestrae famosissimum scelus et inopinata crudelitas terram concutit et percutit caelum, ut in plateis ac delubris uestris eluceat sanguis et resonet homicidium. Apud uos Romanae sepultae sunt leges, iudiciorum rectorum calcatu!s est terror, imperatorum certe nulla ueneratio nec timor. Apud uos sexaginta numero fratrum innocens effusus est sanguis et, si quis plures occidit, functus est laudibus et in uestram curiam tenuit principatum. Age nunc, principalem ueniamus ad causam! Si Herculem uestrum dixeritis, porro reddemus: adsunt metalla, saxa nec desunt; accedunt et marmorum genera, suppeditat artificum copia. Ceterum deus uester cum diligentia sculpitur, tornatur et ornatur; addimus et rubricam quae pingat ruborem, quo possint uota uestra sacra sonare. Nam si uestrum Herculem dixeritis, conlatis singulis nummis ab artifice uestro uobis emimus deum. Reddite igitur animas, quas truculenta uestra manus contorsit, et sicuti a nobis uester Hercules redhibetur, sic etiam a uobis tantorum animae reddantur!

\section{NOTES}

1. Texte établi par A. Goldbacher, CSEL 34/2 (Corpus Scriptorum Ecclesiasticorum Latinorum, 1898), p. 143.

\section{AUTHOR}

\section{AUGUSTIN}

Augustin d'Hippone (354 - 430) 